\title{
Influence of parasitic invasions on the values of malondialdehyde and ceruloplasmin in horses
}

\author{
(C) Larisa V. Pilip, ${ }^{+}$Olga V. Byakova, ${ }^{*}$ and Maria E. Kazakova \\ Chair of Zoohygiene. Physiology and Biochemistry. Vyatka State Agricultural Academy. \\ Oktyabrsky Ave., 133. Kirov, 610000. Russia.Phone:+7 999100 8078. E-mail: pilip_larisa@mail.ru
}

*Supervising author; ${ }^{+}$Corresponding author Keywords: lipid peroxidation, horses, parasitic invasions, malondialdehyde, ceruloplasmin, santoquine, antioxidants.

\begin{abstract}
Parasitic invasions in horses often cause metabolic disorders and have a negative impact on their health and performance. The purpose of this research was to study the processes of lipid peroxidation and antioxidant protection in horse helminthiases, as well as following the deworming with a drug containing the antioxidant santoquine. The intensity of lipid peroxidation and antioxidant protection was determined in horses with different degrees of invasion by concentrations of malondialdehyde and ceruloplasmin accumulated in the blood. The studies have revealed that the concentration of malondialdehyde, the end product of free radical oxidation of cell membrane phospholipids, depends on the intensity of infestation with intestinal nematodes. In horses infested with paraskaris and intestinal strongylata, a significant accumulation of malondialdehyde was by $18.2 \%$ higher as compared to uninfected animals. The level of ceruloplasmin was significantly lowerby $21.8 \%$ in animals with a moderate degree of invasion as compared to clinically healthy animals. To neutralize free radicals the antioxidant santoquine was used. Effective deworming by means of using santoquine reduced the intensity of lipid peroxidation processes, which resulted in a significant decrease in the concentration of malondialdehyde by $22.1 \%$ and an increase in the level of ceruloplasmin against the background of the lower rate of free radical oxidation by $25.8 \%$.
\end{abstract}

\section{References}

[1] D.D. Adjiev. Lipid peroxidation products and nonenzymatic and enzymatic antioxidant systems in male rabbits: age dynamics. VOGiS Herald. 2010. Vol.14. No.4. P.674-684. (russian)

[2] L.A. Bundina, S.V. Engashev. Prevalence of intestinal nematodes and effectiveness of horse deworming in sport clubs of Moscow region. Veterinary Medicine. 2015. No.5. P.32-35. (russian)

[3] O.V. Byakova, L.V. Pilip. Lipid peroxidation and natural resistance in horse helminthiases. Monograph. Raduga-PPESS Publ., Federal State Budgetary Institution of Higher Education Vyatka State Agricultural Academy (Kirov). 2018. 149p. (russian)

[4] O.V. Byakova, L.V. Pilip, S.N. Belozerov. Lipid peroxidation as factor of endogenous intoxication in helminthiases. Russian Journal of Parasitology. 2008. No.2. P.52-55. (russian)

[5] O.V. Byakova, L.V. Pilip. Lipid peroxidation in intestinal nematodoses of horses. Vestnik Veterinarii. 2012. No.4(63). P.28-30. (russian)

[6] S.V. Engashev, E.Kh. Daugalieva, M.D. Novak. Antihelmintic drugs for veterinary practice and their effectiveness. Training manual. Ryazan. 2015. 100p. (russian)

[7] K.A. Moshkov, V.N. Zaitsev, E.V. Romanovskaya, V.E. Stefanov. Ceruloplasmin: intramolecular electron transfer and ferroxidase activity. Fundamental Research. 2014. No.3-1. P.104-108. (russian)

[8] L.V. Pilip, O.V. Byakova, and M.E. Kazakova. Specific features of biological oxidation processes in helminthiases of horses. Butlerov Communications. 2020. Vol.61. No.3. P.126-130. DOI: 10.37952/ROIjbc-01/20-61-3-126

[9] A. Bliska, L. Wlodek. Biologic properties of lipoic acid. Postepy Hig. Med. Dosw. 2002. Vol.56. P.201-219.

[10] P.M. Clarkson, H.S. Thompson. Antioxidants: what role do they play in physical activity and health? Am. J. Clin. Nutr. 2000. Vol.72. No.2. P.637-646.

[11] C.M. Deaton, D.J. Marlin, C.A. Roberts et al. Antioxidant supplementation and pulmonary function at rest and exercise. Equine Vet. J. Suppl. 2002. No.34. P.58-65. 